\title{
CABO Regimen
}

National Cancer Institute

\section{Source}

National Cancer Institute. CABO Regimen. NCI Thesaurus. Code C63689.

A regimen consisting of cisplatin, methotrexate, bleomycin and vincristine used for the treatment of unresectable and recurrent head and neck squamous cell carcinoma. 